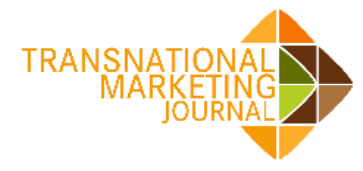

\title{
Spillover effect of COVID19 on the Global Economy Hasnan Baber ${ }^{1}$
}

\begin{abstract}
The pandemic of COVID19 has disrupted every aspect of life. From groceries to medicines, travel to events, sports to funerals, economics to politics and religion to social rights all domains of life have been shaken up by this infectious virus. The impact is deep and will have a lasting effect. The situation is severe in some countries and it is too soon to estimate the exact impact of COVID19 on the global economy. This is a review article examining different facets of the pandemic to understand the impact on the economy. This article examines the effect of this crisis on the financial markets, banking, hospitality, and health care sectors. The data comes from various reports published by the various organizations and institutions worldwide and the recent limited research literature available on this topic. The bitter truth is that the pandemic will have a substantial and extended negative impact on the global economy, especially on the financial and hospitality industry.
\end{abstract}

Keywords: COVID19; economy; hospitality; tourism; financial; banking; spill-over; healthcare; coronavirus.

\section{Introduction}

The pandemic of COVID 19 has changed the way of living. Pandemic has an economic cost associated with it (Goodell, 2020). Various studies focused on the economic cost of past pandemics like HIV/AIDS (Haacker, 2004; Santaeulalia-Llopis, 2008). The costs associated with the current pandemic of COVID19 can be: cost to health, the crash of stock market; negative economic growth, impact on the hospitality industry and tourism, banks, and list go on. The Pandemic of COVID19 started on 31st December 2019 after the World Health Organization (WHO) witnessed the first case in Wuhan, China. Over the period the infection spread in the other parts of China. The infection started to spread in neighbouring countries like South Korea as the travel restrictions were not in place. On 30th January 2020, WHO declared the global health emergency and it was the sixth time in history that such an emergency was declared. As reported by BBCAsia, on 7th February ${ }^{2}$ reported the death of Dr. Li, he was an ophthalmologist, was first who posted his story on Weibo about the

\footnotetext{
1 Hasnan Baber, Endicott College of International Studies, Woosong University, Daejeon, South Korea. Email: h.baber@endicott.ac.kr

2 https://www.bbc.com/news/world-asia-china-51403795
} 
infection, China's equivalent of Twitter, from a hospital bed a month ago. In his Weibo post he describes how on 10th January he started coughing, the next day he had a fever and two days later he was in the hospital. On $11^{\text {th }}$ March 2020, WHO declared this virus as pandemic based on the spread in all over the world. Though the fatality rate of this virus is not so high as compared to the previously known pandemics, however, the infection rate of the virus is high as shown in table 1. In order to understand the infection rate and fatality rate of this pandemic, it is important to first understand the $R$ of this virus COVID 19. The $R$ number refers to the basic reproduction number, known as the $\mathrm{R}$ nought or zero (Ro), or the effective reproduction number $(R e)$. Presuming that there is no pre-existing immunity in the public against the virus, RO means the number of people each infected person will further infect on an average.

The effective reproduction number, Re, also called Rt, is the number of people in a community who can be infected by an individual at any specific time. It will change as the population may get gradually immunized, which can occur either by building individual immunity following infection or by vaccination, and also by a reduction in population as people die. The most important point is that if $\mathrm{Rt}$ is above 1.0, the virus will spread quickly and is dangerous. When Rt is below 1.0, the virus will spread slowly and eventually will die. In a report on 23rd January 2020 about the outburst of COVID-19 WHO gave a preliminary R0 estimate of 1.4-2.5. Let's see how it works if the disease has an R of 1.5 and 1000 people are infected. They are going to infect 1500 people who will further infect 3750 people as shown in figure 1 . As worldwide cases now exceed 10 million on 29th June, this helps explain why the coronavirus was able to spread so quickly across the borders with no previous immunity.

The $R$ is important so that we can compare this pandemic with previous pandemics and can anticipate the economic losses at this time. The $\mathrm{R}$ helps countries to be ready for the future number of cases, policies regarding lockdown and unlock, policies for healthcare and social distancing, announcing more economic packages, and restarting economic activities. If the R-value is low, countries can unlock and start economic activities. It is also important to understand the $R$ so that future studies differentiate the effects of different values of $R$ with the impact on the economy, financial markets, health care, and tourism industry. 
Table 1. Overview of previously known pandemics and COVID19

\begin{tabular}{|c|c|c|c|c|c|c|c|}
\hline 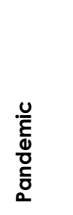 & 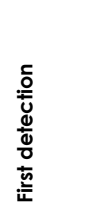 & 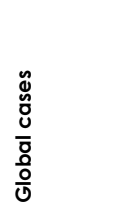 & $\begin{array}{l}\frac{n}{5} \\
\frac{0}{0} \\
\frac{0}{0} \\
\frac{0}{0} \\
\frac{0}{0}\end{array}$ & 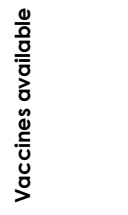 & 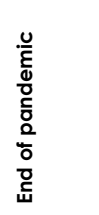 & 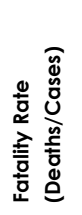 & 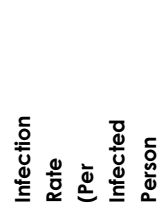 \\
\hline 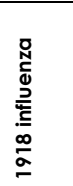 & $\begin{array}{l}\text { March } \\
1918\end{array}$ & 500 million & $\begin{array}{l}\text { Over } \\
50 \text { million }\end{array}$ & none & $\begin{array}{l}\text { summer } \\
1919\end{array}$ & - & - \\
\hline 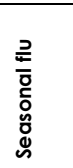 & - & $\begin{array}{l}1 \text { billion } \\
\text { infections }\end{array}$ & $\begin{array}{l}\text { between } 291,000 \\
\text { to } 646,000\end{array}$ & $\begin{array}{l}\text { many } \\
\text { vaccine } \\
\text { options }\end{array}$ & - & $\begin{array}{l}1 \%- \\
3.4 \%\end{array}$ & 1.3 \\
\hline 岕 & $\begin{array}{l}\text { Nov. } \\
2002\end{array}$ & $\begin{array}{l}8,098 \\
\text { cases }\end{array}$ & 774 & $\begin{array}{l}\text { Around } \\
\text { the end of } \\
\text { Pandemic }\end{array}$ & $\begin{array}{l}\text { July } \\
2003\end{array}$ & $10 \%$ & 3 \\
\hline$\underset{\mathbf{z}}{\underline{x}}$ & $\begin{array}{l}\text { January } \\
2009\end{array}$ & $\begin{array}{l}\text { about } \\
24 \text { per } \\
\text { cent of the } \\
\text { global } \\
\text { population }\end{array}$ & $\begin{array}{l}\text { over } \\
284,000\end{array}$ & $\begin{array}{l}\text { December } \\
2009\end{array}$ & $\begin{array}{l}\text { August } \\
2010\end{array}$ & - & - \\
\hline $\begin{array}{l}\text { 응 } \\
\text { 욘 }\end{array}$ & $\begin{array}{l}\text { Dec. } \\
2013\end{array}$ & $\begin{array}{l}28,652 \\
\text { cases }\end{array}$ & 11,325 deaths & none & $\begin{array}{l}\text { March } \\
2016\end{array}$ & $50 \%$ & $1.5-2.5$ \\
\hline فे & $\begin{array}{l}\text { Dec. } \\
2019\end{array}$ & $20,257466^{*}$ & 738,956* & none yet & - & $1.4 \%^{*}$ & $1.5-3.5$ \\
\hline 总 & - & 2,519 & 866 & $\begin{array}{l}\text { No } \\
\text { vaccine }\end{array}$ & - & $34.30 \%$ & $0.42-0.92$ \\
\hline
\end{tabular}

Source: Asian development bank report No. 128 (https://www.adb. org/publications/economicimpact-covid 19-developing-asia) and Healthline, 2020 (https://www.healthline.com/healthnews/how-deadly-is-the-coronavirus-compared-to-past-outbreaks)*on $11^{\text {th }}$ August 2020, (Worldometer, 2020) 
Figure 1. How 1000 cases would increase under different infection rates. Source: BBC

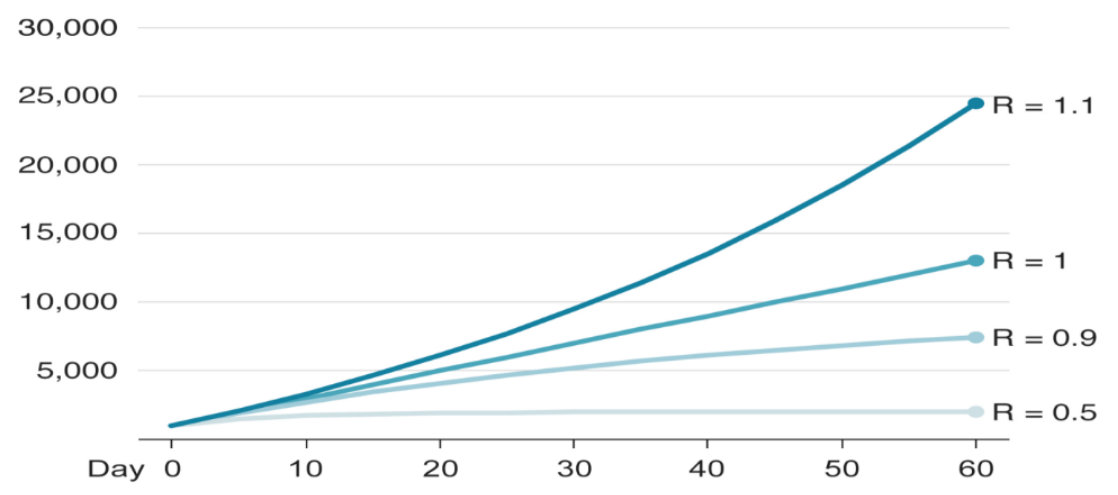

BBDC

Figure 2. Stringency index in March 2020 Source: Hale, et al., (2020).

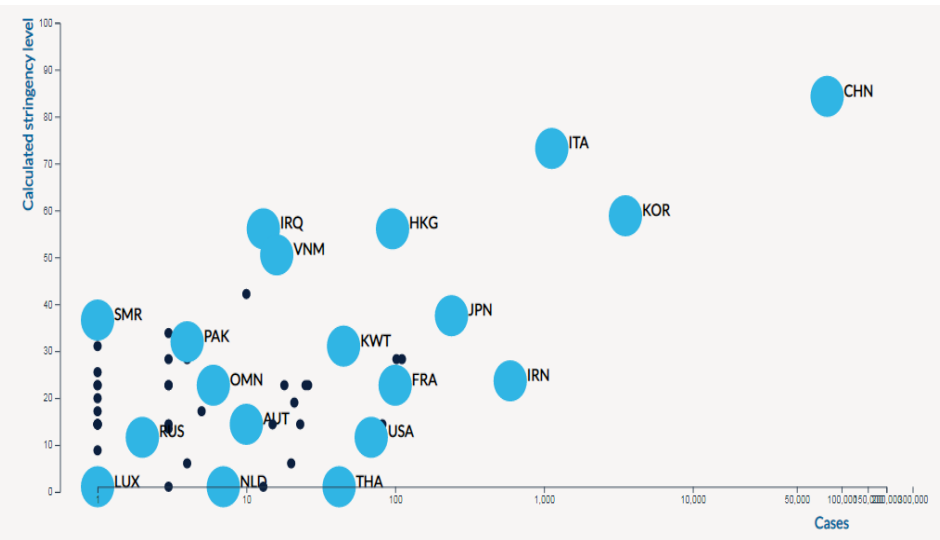

1 1Mad

Lockdown was the only way for countries to slow down the spread or decrease the Rt. Some countries announced lockdown early while anticipating the crisis while some countries never went for lockdown. The start of lockdown was strict while restricting all the movements of citizens but over the period relaxation was given in some countries which were successful in keeping the Rt below 1. As the cases were declining in many countries, the government was under pressure to ease the restriction and allow some business establishments to start. The two figures $2 \& 3$ show imposition and gradually relaxation in the lockdown in March and on 28th June respectively. Researchers at Oxford University developed a stringency index- a composite score derived from a database of pandemic-response policies of different

www.tplondon.com/tmj 
countries. Anderson et al., (2020) proposed a SIR model for the economist to anticipate the economic impact of the spread. The model divides the population into three categories-vulnerable to the disease (S), actively contaminated with the disease (I), and recovered or dead (R). The model will help to analyze the tradeoff between then health care and economic stimulus.

Figure 3. Stringency index on $28^{\text {th }}$ June 2020

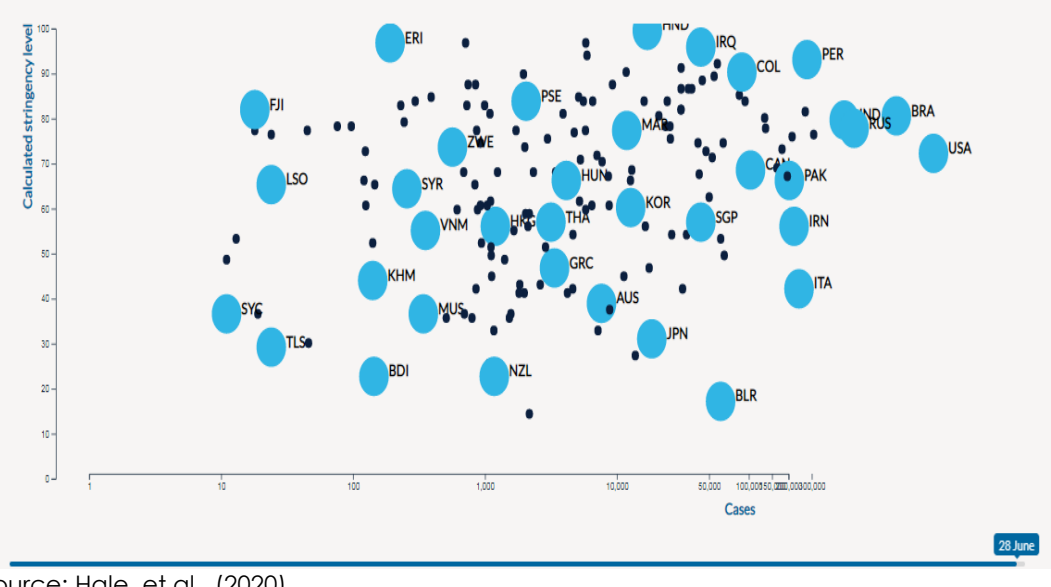

Source: Hale, et al., (2020).

\section{Impact on the Global Economy}

Fernandes, (2020) suggested that there is no association between mortality rates and economic fluctuations during the COVID19 crisis. The rationale of no association may be the simultaneous demand and supply shocks that are stimulated by the reaction of governments, businesses, customers, and mass media. However, Ding et al., (2020) stated that an average increase in COVID19 over two months has resulted in a 12 percent drop in the stock prices all over the world. So, there is a negative relation to the economy's exposure to the COVID19 pandemic. Maital, \& Barzani, (2020) suggested that the first impact of COVID19 will be on the supply side due to the closure of factories in China and elsewhere which will eventually lead to price rise called stagflation. Dietrich et al., (2020) conducted a survey to examine the household expected loss from the COVID19 pandemic in the US and suggested that people were optimistic in the beginning; however, by the end of March, they were anticipating the loss by $15 \%$ and rise in prices by 5 percentage points.

Major public health emergencies, such as SARS in 2003 and influenza A (HIN1) in 2009, have all had a systemic negative impact on international economy and social development (Madhavet et al., 2017). The same may be true for the COVID19 in 2020. Fernandes, 
(2020) denied and disapproved of the comparison of this crisis with other global crises, like the 2008 financial crisis. The reason may be that a) it is a global pandemic b) it is going to affect all the income segments c) interest rates are at its record low d) simultaneous demand and supply shocks e) international integration and dependency. Tourism, hotel, aviation industry, and other related industries have also been severely hit, which greatly affected the economy as a whole. Studies have been done to highlight the economic risks associated with the likelihood of pandemic (Bloom, \& Canning, 2004; Madhav et al. 2017). The economic situation across the various regions in the world is shown in Appendix (A) keeping the real GDP growth as an indicator. Almost all regions are witnessing an approximately $100 \%$ decrease in the annual percent change of the real GDP growth. Only two regions- South Asia and Emerging and Developing Asia are showing positive economic growth in 2020. The COVID-19 crisis exploded and outspread with incredible speed. Let's take an example of the US. In February 2020, the unemployment rate was at $3.5 \%$, tallying its lowest rate in the past 67 years. A mere six weeks later, the position has moved severely: Nearly ten million Americans filed for unemployment benefits in the past two weeks (Chaney and Morath, 2020). Sumner, Hoy, \& Ortiz-Juarez, (2020) stated that the COVID19 pandemic will increase the number of poor people who are living on a $\$ 1.9 /$ day poverty line by 80 million and UN Sustainable Development Goal of ending poverty by 2030 is looking a serious challenge. Several studies have found that the health of the population evaluated by the mortality rate, life expectancy, is significantly associated with economic growth (Bhargava et al., 2001; Haacker, 2004).

\section{Banking}

Banks usually do not get directly affected by a pandemic however there will be a severe causal effect on its profit. The non-performing loans will soar amid and post-pandemic. Business is shut in most of the countries and may not able to pay their loans back on time or in the worst case, not at all. The businesses which may not be able to pay their loans include hotels, restaurants, airlines, retailers, real estate, contractors, transporters, etc. Lagoarde-Segot, \& Leoni, (2013) proposed a model that predicted the chances of banks to go collapse in developing countries during the pandemic is high. The banking transactions were expected to reduce as people stayed back at home and maintained social distance. However, Ozili, \& Arun, (2020) claimed that even card payments and FinTech transitions declined during the pandemic. Shahabi et al., (2020) suggested that the outbreak of COVIDI9 has played a key role in changing the attitude of people towards branchless banking in Iran. Banks has 
insulated itself from the impact of Covid 19 and witnessed an increase in online banking and digital payments amid the pandemic crisis. The interesting scenario is that banks and customers who were reluctant to go online have shifted swiftly towards digitization during the pandemic (Seetharaman, 2020; Aver, Cornelli, \& Frost, 2020).

People who lost their job or shut their business may also seek loans from banks to cover their expenses which increase the credit risk of banks. Ozili, \& Arun, (2020) stated that non-performing loans in the banking sector have already increased during this pandemic. The private banks have high credit risk as compared to public banks. The banks may have to change their lending policies amid and postpandemic. Some of the initiatives taken by various central banks across the countries are shown in table 2 .

Table 2. Central bank Initiatives

\begin{tabular}{|c|c|}
\hline Bank & Initiatives \\
\hline $\begin{array}{l}\text { US Federal Reserve (The } \\
\text { FED) }\end{array}$ & $\begin{array}{l}\text { Cut federal funds rate by } 50 \text { basis points } \\
\text { Added additional liquidity of more than } \$ 3 \\
\text { trillion }\end{array}$ \\
\hline Bank of Japan (BoJ) & $\begin{array}{l}\text { Issued statement to increase in asset } \\
\text { purchase to stimulate liquidity } \\
\text { Provided } \$ 43 \text { bn bank liquidity }\end{array}$ \\
\hline $\begin{array}{l}\text { People Bank of China } \\
\text { (PBOC) }\end{array}$ & $\begin{array}{l}\text { Injected more than } \$ 240 \mathrm{bn} \text { in the economy to } \\
\text { increase liquidity }\end{array}$ \\
\hline Bank of England & $\begin{array}{l}\text { New lending facility among larger firms } \\
\text { Cut interest rate to } 0.1 \mathrm{pc}\end{array}$ \\
\hline $\begin{array}{l}\text { European Central Bank } \\
\text { (ECB) }\end{array}$ & $\begin{array}{l}\text { Announced 750bn Euros asset-purchase } \\
\text { program }\end{array}$ \\
\hline Central bank of Russia & $\$ 4$ billion induced in economy \\
\hline Reserve bank of Australia & $\$ 56$ billion stimuli for liquidity \\
\hline
\end{tabular}

Policies are required in the short term by central banks and treasuries to keep the economy functioning during the pandemic as well as in long term to help economies revive to return to past normal and then growth stimulus. Though the reduction in interest rates will lessen the shock from the demand side long term monetary, fiscal, and health policies should be developed and implemented (McKibbin, \& Fernando, 2020). Other than the monetary and fiscal policies which some countries have already initiated, social and economic costs can be reduced by quarantining infected people and sanitization practices (Levine and McKibbin, 2020). Aldasoro et al., (2020) stated that forceful policy measures taken by the central banks has favored banks and subsequently banks reported high profits and healthy balance sheet. Banks were anticipating the disruption in the cash 
inflows from credit lines and loan commitments, however, monetary and fiscal policies helped banks to accommodate the liquidity demands (Li, Strahan, \& Zhang, 2020). Flögel, \& Gärtner, (2020) suggested that the COVID19 pandemic differs from the financial crisis and Hausbanks (relationship/local banks) in Germany can support business clients to survive amid the social shutdown and provide a cushion against the adverse economic bearings of the pandemic.

\section{Financial Market}

Stock markets are quite interlinked all over the world. Crisis in one part of the world influences the stock market of other parts (Morales, \& Andreosso-O'Callaghan, 2012). Globalization and interdependence of countries on each other have made them susceptible to the crisis in any part of the world. There is a cross-market association during the crisis (Liu et al., 2020). Sun and Hou (2019) stated that most of the countries in Southeast Asia like Malaysia, Vietnam, and Thailand are financially unified with China. Any shock to the Chinese economy has deep repercussions on the world economy as China represents $16 \%$ of the world economy as compared to 3\% in 2003 (Fernandes, 2020). Emergencies like a pandemic or endemic eruptions can prompt a negative trend in investors' sentiment that strongly affects their financing decisions and, eventually, impacts stock market prices. Several reputed companies' stocks plunge more than $80 \%$ in a few days and stocks around the world witnessed the biggest one-day falls (Fernandes, 2020). Mishra, Rath, \& Dash, (2020) examined the impact of COVID19 on the Indian financial market and compared it to financial shocks after the demonetization and implementation of the GST (Goods and Services Tax). The study found the negative impact of this pandemic on the stock prices as compared to previous financial shocks due to demonetization and implementation of the GST (Goods and Services Tax).

Liv et al., (2020) researched to check the immediate effect of COVID19 on the stock markets of the major affected countries. The research concluded that the COVID-19 pandemic has a substantial adverse impact on stock market returns across all distressed countries and areas. The same results were found by the He, Liu, Wang, \& Yu, (2020) but suggest a short-term impact on stock markets of affected countries. The spread of viruses has reduced the production rate in China disrupting the supply chain but on the other hand, consumption has also reduced because of lockdown and social distancing (Wall St. J., 2020). Ozili, \& Arun, (2020) suggested that increasing lockdown days, international travel restrictions, and monetary policy rates have influenced the economic activities of the country. The same study while doing the analysis found that surge in 
confirmed cases has a positive influence on the highest, opening, and lowest prices of major stock indices.

\section{Travel and Tourism}

In recent years, with the development of people's living standards, domestic and foreign tourism develops rapidly. As a wide-ranging industry, tourism has a strong dependence on the natural environment, politics, and social environment. The countries have immediately suspended tourism activities and aviation operations after the pandemic outbreak. While some countries e.g. India placed a complete ban on domestic and international flights while some countries like South Korea, only suspended travel with countries restricted inbound flights. Some big aviation companies like Emeritus lay off thousands of pilots and cabin crew their employees due to a decrease in demand domestically and internationally. The aviation industry is set loose $\$ 84$ billion this year, which is 3.2 times higher than in the Global Financial Crisis according to International Air Transport Association (IATA). However, the losses in 2021 will modest to $\$ 16$ billion with the increase of revenues, and the EBIT (Earnings before Interest and Tax) margin will improve from $-23.4 \%$ to $-4.2 \%$ as shown in figure 4 . Airlines are set to aid from the government of $\$ 123$ billion but they must repay around half of the amount. Aid has been very haphazardly spread across countries and regions. Whilst governments in North America and Europe have provided aid equivalent to $25 \%$ and $15 \%$ of regional airline revenues respectively, the same figure in Latin America, the Middle East, and Africa has been only about $1 \% 3$ Obviously, countries like Greece, Portugal, Mexico, or Spain that are more reliant on tourism (more than 15\% of GDP) will be more affected by this crisis (Fernandes, 2020).

According to the World Travel and Tourism Council, the tourism industry may lose 50 million jobs worldwide. Up to June 2020, if we take an optimistic scenario and assume that restriction will ease from June for domestic and international travel in august then $30 \%$ of Jobs will be lost, $41 \%$, and $26 \%$ decrease in international and domestic travel respectively. lacus et al., (2020) suggested that there will be 35.7 million job losses in tourism catalytic (tourism and its value chain hotels, restaurants, etc). Also 7.8 million job losses due to spending of those directly or indirectly employed in the aviation sector and 10.8 million job losses in indirect impact which is concerned with employment and economic activity created by suppliers to the

3 https://www.iata.org/en/iata-repository/publications/economic-reports/record-loss-in-2020extending-to-2021-but-at-a-lower-level/

(c) 2020 TRANSNATIONAL MARKETING JOURNAL - Transnational Press London 
aviation industry: aviation fuel suppliers, etc. Around 10.2 million job losses in the direct aviation industry.

Figure 4. Record loss in 2020

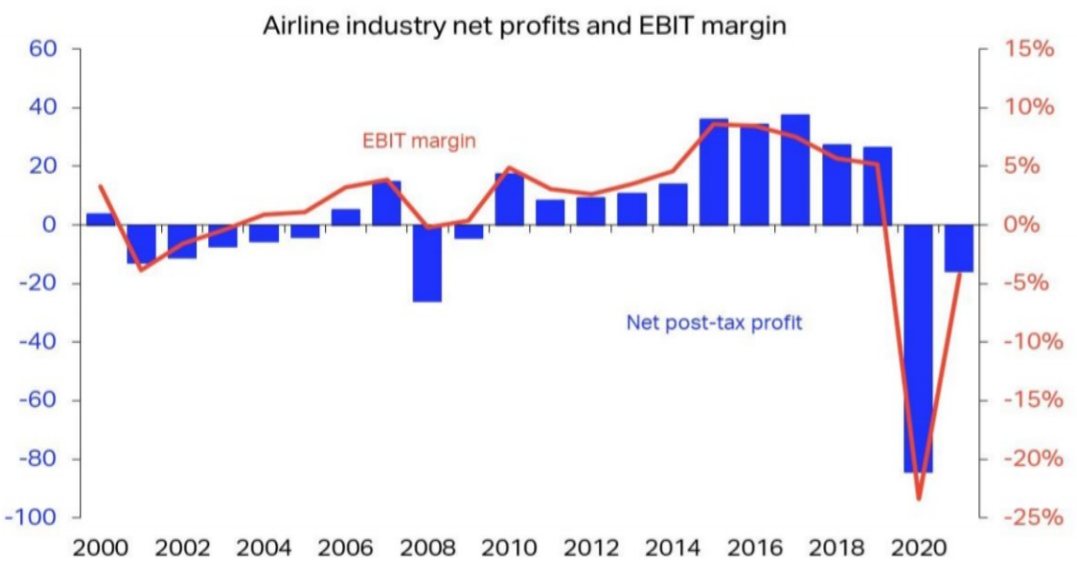

Source: IATA Economic Performance of the Airline Industry, June 2020

Table 3. Tourism industry forecast under different scenarios

\begin{tabular}{|l|l|l|l|l|l|l|}
\hline & Upside & & Baseline & & $\begin{array}{l}\text { Downsid } \\
\text { e }\end{array}$ & \\
\hline & $\begin{array}{l}\text { Job } \\
\text { Losses }\end{array}$ & $\begin{array}{l}\text { GDP } \\
\text { Losses }\end{array}$ & $\begin{array}{l}\text { Job } \\
\text { Losses }\end{array}$ & $\begin{array}{l}\text { GDP } \\
\text { Losses }\end{array}$ & $\begin{array}{l}\text { Job } \\
\text { Losses }\end{array}$ & $\begin{array}{l}\text { GDP } \\
\text { Losses }\end{array}$ \\
\hline Regions & in million & IN US\$BN & in million & IN US\$BN & in million & IN US\$BN \\
\hline Asia Pacific & -59.7 & -980 & -69.3 & $-1,137$ & -115 & $-1,888$ \\
\hline Europe & -14.2 & -771 & -18.4 & $-1,000$ & -29.5 & $-1,608$ \\
\hline EU & -8.8 & -568 & -11.4 & -739 & -18.3 & $-1,187$ \\
\hline Africa & -7.6 & -53 & -10.9 & -75 & -17.4 & -120 \\
\hline Americas & -14 & -783 & -19.2 & $-1,098$ & -30.7 & $-1,750$ \\
\hline $\begin{array}{l}\text { North } \\
\text { America }\end{array}$ & -8.1 & -673 & -11.4 & -955 & -18.2 & $-1,520$ \\
\hline $\begin{array}{l}\text { Latin } \\
\text { America }\end{array}$ & -4.7 & -84 & -6.1 & -109 & -10.4 & -185 \\
\hline Caribbean & -1.2 & -27 & -1.6 & -34 & -2 & -44 \\
\hline Middle East & -2.7 & -99 & -3.4 & -125 & -4.9 & -179 \\
\hline World & -98.2 & $-2,686$ & -121.1 & $-3,435$ & -197.5 & $-\mathbf{5 , 5 4 3}$ \\
\hline
\end{tabular}

Source: The World Travel \& Tourism Council (WTTC), June 2020.

The worst-case respectively than there will be $60 \%$ of job loss and a $62 \%$ decline in GDP contribution of this industry. Removal of quarantine and bans on non- essential international travel will help to start tourism. However, health protocols must be followed for a long period. As per the survey of IATA in May-June, $85 \%$ of people were

www.tplondon.com/tmj 
concerned about quarantine while $84 \%$ of people are concerned about getting a virus during travel. Even after travel restrictions are eased, the quarantine will be a greater concern for travelers. These quarantine curbs jeopardize to crash the tourism and hospitality industry; accommodation services have ground to a cease, and restaurants are not operating to their full capacity (Wen et al., 2020). Hoque et al., (2020) suggested the negative impact of covid 19 on the tourism of China and may last for some time. Gössling, Scott, \& Hall, (2020) suggested the COVID-19 pandemic can be used as an opportunity to critically reassess tourism's growth curve, and to examine the rationality of more arrivals implying greater profits. Zheng, Goh, \& Wen, (2020) insisted on balanced and fair media coverage on covid 19 virus to minimize the damage of international tourism in China.

\section{Healthcare}

Health care is facing an unprecedented challenge across the countries. The health care workers including doctors, nurses, and paramedical staff are most vulnerable to the disease than any anyone else. This sector cannot work from home as other workers are doing and thus require better facilities, equipment, protection, regular testing, and quarantine facilities upon any symptoms (Tanne et al., 2020). The industry saw its largest decline in the last three decades, with 43,000 jobs cut, according to the US Bureau of Labor Statistics. Only 200 jobs were created in March 2020.4 The healthcare system was exposed as there was a shortage of basic facilities like low numbers of ICU beds and ventilators and personal protective equipment (PPE). High testing costs in developing countries has put an extra financial burden on the citizens amid the financial choke in most of the countries. Uninsured citizens in developed countries like the US are getting hefty bills after discharge. Those who are hospitalized with COVID 19 can expect to pay anywhere from $\$ 42,486$ to $\$ 74,310$ (Tolbert, 2020 ) if they are uninsured or if they receive care that's deemed out-of-network by their insurance company, according to a recent analysis by independent nonprofit FAIR Health. ${ }^{5}$ Most of the supply chain has been disrupted which includes the pharmaceutical supply chain. China is producing around $60 \%$ of the world's active pharmaceutical ingredients (API) and because of the shutdown of factories, this supply was interrupted. The lesson of

\footnotetext{
4 https://www.docwirenews.com/docwire-pick/covid-19s-economic-effect-on-the-healthcareindustry/

5 https://www.cnbc.com/2020/04/01/covid-19-hospital-bills-could-cost-uninsured-americans-upto-75000.html
}

(C) 2020 TRANSNATIONAL MARKETING JOURNAL - Transnational Press London 
not relying on only one country for essential API should be learned and executed in the future.

In the US, there is a lot of criticism about the lack of coordination among the states and lack of clear communication from the white house (Tanne et al., 2020). South Korea with its advanced health care was able to put brakes on the spread at the right time. Health care alone is not responsible for flattening the curve; it is an efficient method of tracking and testing by the administration. This method has gained a lot of appreciation and applause from the rest of the world and has become the standard of operation procedure. The health care in India is not so well developed as there are only 1.3 hospital beds for every 1000 people versus the recommended number of 3.5 by WHO. ${ }^{6}$ Although the government in India has enforced strict lockdown for a period of about two months, the number of cases is still rising. The rise in the number of cases has put a strain on the existing health system especially in the capital city of Delhi. Spain was once among worst-hit countries by COVIDI9 and faced sever patient overload. Many health workers were infected or quarantined which further created chaos. Though the health system of Spain is better, however, the overcapacity of patients leads to the shortage of personal protective equipment (PPE). Likewise, France and Germany were hit hard, and a surge in cases led to the overburden on the existing healthcare, however, it managed well so far. Australia kept the things very much under control although the positive test reports of US actors Tom Hanks and Rita Wilson catches the media attention. Singapore was somehow successful in coping with a growing number of cases with good management and healthcare facilities.

The impact on the mental and psychological health cannot be undermined during the lockdown and pandemic. The mental health of students is also affected during the health crisis and at the same time continuing their studies online during the sudden shift towards online learning (Cao et al., 2020; Baber 2020). There should be counseling sessions to these students from the government and schools to provide timely crisis-oriented psychological services.

\section{Conclusion}

The pandemic of covidl9 has had a negative impact on the economy in general and some industries are the worst victims of this crisis. The central banks of countries had initiated their effort to minimize the damage by inducing liquidity and changing lending policies. However, more stimulus financial packing will be needed in

\footnotetext{
6 PWC. Future of India: the winning leap. 2014. https://www.pwc.com/sg/en/publications/assets/ future-of-India-the-winning-leap.pdf.
}

www.tplondon.com/tmj 
order to revive the economy slowly. The goal is not to be conclusive about the virus spate, but rather to provide a solution to a range of possible economic costs of the infection. Financial markets have seen the impact and now will need time to get back the positive investor sentiments. The tourism and hospitality industry is going through the worst phase from the time of inception and may need social investment to survive and then revive during this period. Enhancing healthcare facilities should be a priority for any government to mitigate the post-pandemic effects. The response in China against the COVID19 is impressive so far being the largest population in the world however, this model can be replicated is not clear. Countries that were affected by severe acute respiratory syndrome (SARS) epidemics in 2002-03 have some experience to deal with such a health crisis has controlled the spread early through social distancing and testing model.

\section{References}

Aldasoro, I., Fender, I., Hardy, B., \& Tarashev, N. (2020). Effects of Covid-19 on the banking sector: the market's assessment (No. 12). Bank for International Settlements.

Anderson, R. M., Heesterbeek, H., Klinkenberg, D., \& Hollingsworth, T. D. (2020). How will country-based mitigation measures influence the course of the COVID-19 epidemic?. The Lancet, 395(10228), 931-934.

Auer, R., Cornelli, G., \& Frost, J. (2020). Covid-19, cash, and the future of payments (No. 3). Bank for International Settlements.

Baber, H. (2020). Determinants of students' perceived learning and satisfaction in online learning during the pandemic of COVID 19. Journal of Education and E-Learning Research, 7(3), 285-292

Bhargava, A., Jamison, D. T., Lau, L. J., \& Murray, C. J. (2001). Modeling the effects of health on economic growth. Journal of health economics, 20(3), 423-440.

Bloom, D. E., \& Canning, D. (2004). Epidemics and economics. Interactions Between Global Change and Human Health (Scripta Varia, 106, 304-331.

Cao, W., Fang, Z., Hou, G., Han, M., Xu, X., Dong, J., \& Zheng, J. (2020). The psychological impact of the COVID-19 epidemic on college students in China. Psychiatry research, 112934.

Chaney, Sarah and Eric Morath, 2020. "Record 6.6 Million Americans Sought Unemployment Benefits Last Week," Wall Street Journal, 3rd April.

Deloitte insights 2020, Banking and capital markets: implications of COVID-19 I deloitte insights [Internet]. [cited 2020 Mar 20]. Available from: https://www2.deloitte.com/global/en/insights/economy/covid19/banking-and-capital-markets-impact-covid-19.html

Dietrich, A., Keuster, K., Müller, G. J., \& Schoenle, R. (2020). News and uncertainty about covid-19: Survey evidence and short-run economic impact. 
Ding, W., Levine, R., Lin, C., \& Xie, W. (2020). Corporate immunity to the COVID-19 pandemic (No. w27055). National Bureau of Economic Research.

Fernandes, N. (2020). Economic effects of coronavirus outbreak (COVID-19) on the world economy. Available at SSRN 3557504.

Flögel, F., \& Gärtner, S. (2020). The COVID-19 Pandemic and Relationship Banking in Germany: Will Regional Banks Cushion an Economic Decline or is A Banking Crisis Looming?. Tijdschrift voor economische en sociale geografie, 111 (3), 416-433.

Goodell, J. W. (2020). COVID-19 and finance: Agendas for future research. Finance Research Letters, 101512.

Gössling, S., Scott, D., \& Hall, C. M. (2020). Pandemics, tourism and global change: a rapid assessment of COVID-19. Journal of Sustainable Tourism, $1-20$.

Haacker, M. (2004). The impact of HIV/AIDS on government finance and public services. The macroeconomics of HIVIAIDS.

Hale, T., Webster, S., Petherick, A., Phillips, T., \& Kira, B. (2020). Oxford COVID19 government response tracker. Blavatnik School of Government, 25.

He, Q., Liu, J., Wang, S., \& Yu, J. (2020). The impact of COVID-19 on stock markets. Economic and Political Studies, 1-14.

Hoque, A., Shikha, F. A., Hasanat, M. W., Arif, I., \& Hamid, A. B. A. (2020). The effect of Coronavirus (COVID-19) in the tourism industry in China. Asian Journal of Multidisciplinary Studies, 3(1), 52-58.

lacus, S. M., Natale, F., Santamaria, C., Spyratos, S., \& Vespe, M. (2020). Estimating and projecting air passenger traffic during the COVID-19 coronavirus outbreak and its socio-economic impact. Safety Science, 104791.

Lagoarde-Segot, T., \& Leoni, P. L. (2013). Pandemics of the poor and banking stability. Journal of Banking \& Finance, 37(11), 4574-4583.

Levine, D. I., \& McKibbin, W. (2020). Simple steps to reduce the odds of a globa I catastrophe. The Brookings Institution.

Liu, H., Manzoor, A., Wang, C., Zhang, L., \& Manzoor, Z. (2020). The COVID-19 outbreak and affected countries stock markets response. International Journal of Environmental Research and Public Health, 17(8), 2800.

Li, L., Strahan, P. E., \& Zhang, S. (2020). Banks as Lenders of First Resort: Evidence from the COVID-19 Crisis (No. w27256). National Bureau of Economic Research.

Madhav, N., Oppenheim, B., Gallivan, M., Mulembakani, P., Rubin, E., \& Wolfe, N. (2017). Pandemics: risks, impacts, and mitigation.

Maital, S., \& Barzani, E. (2020). The Global Economic Impact of COVID-19: A Summary of Research. Samuel Neaman Institute for National Policy Research.

McKibbin, W. J., \& Fernando, R. (2020). The global macroeconomic impacts of COVID-19: Seven scenarios.

Mishra, A. K., Rath, B. N., \& Dash, A. K. (2020). Does the Indian Financial Market Nosedive because of the COVID-19 Outbreak, in Comparison to after Demonetisation and the GST?. Emerging Markets Finance and Trade, 56(10), 2162-2180. 
Morales, L., \& Andreosso-O'Callaghan, B. (2012). The current global financial crisis: Do Asian stock markets show contagion or interdependence effects?. Journal of Asian Economics, 23(6), 616-626.

Madhav, N., Oppenheim, B., Gallivan, M., Mulembakani, P., Rubin, E., \& Wolfe, N. (2017). Pandemics: risks, impacts, and mitigation.

Nicola, M., Alsafi, Z., Sohrabi, C., Kerwan, A., Al-Jabir, A., Iosifidis, C., ... \& Agha, R. (2020). The socio-economic implications of the coronavirus and COVID-19 pandemic: a review. International Journal of Surgery.

Ozili, P. K., \& Arun, T. (2020). Spillover of COVID-19: impact on the Global Economy. Available at SSRN 3562570.

Santaeulalia-Llopis, R. (2008). Aggregate effects of AIDS on development. Washington University in St. Louis, Unpublished Manuscript.

Seetharaman, P. (2020). Business models shifts: Impact of Covid19. International Journal of Information Management, 54, 102173.

Shahabi, V., Azar, A., Razi, F. F., \& Shams, M. F. F. (2020). Simulation of the effect of COVID-19 outbreak on the development of branchless banking in Iran: case study of Resalat Qard-al-Hasan Bank. Review of Behavioral Finance.

Sumner, A., Hoy, C., \& Ortiz-Juarez, E. (2020). Estimates of the Impact of COVID-19 on Global Poverty. UNU-WIDER, April, 800-9.

Sun, J., \& Hou, J. W. (2019). Monetary and financial cooperation between China and the One Belt One Road countries. Emerging Markets Finance and Trade, 55(1 1), 2609-2627.

Tanne, J. H., Hayasaki, E., Zastrow, M., Pulla, P., Smith, P., \& Rada, A. G. (2020). Covid-19: how doctors and healthcare systems are tackling coronavirus worldwide. Bmj, 368.

Tolbert . J. (2020). What Issues Will Uninsured People Face with Testing and Treatment for COVID-19?Available from: https://www.kff.org/uninsured/ factsheet/what-issues-will-uninsured-people-face-with-testing-andtreatment-forcovid-19/.

Wen, J., Wang, W., Kozak, M., Liu, X., \& Hou, H. (2020). Many brains are better than one: the importance of interdisciplinary studies on COVID-19 in and beyond tourism. Tourism Recreation Research, 1-4.

Zheng, Y., Goh, E., \& Wen, J. (2020). The effects of misleading media reports about COVID-19 on Chinese tourists' mental health: a perspective article. Anatolia, 31 (2), 337-340. 


\section{Appendix (A). Real GDP growth, 2020}

\begin{tabular}{|l|l|l|l|l|}
\hline Real GDP growth (Annual percent & $\begin{array}{l}\mathbf{2 0 1} \\
\text { change) }\end{array}$ & $\begin{array}{l}\mathbf{2 0 2} \\
\mathbf{9}\end{array}$ & $\begin{array}{l}\text { Percentage } \\
\text { change }\end{array}$ & $\begin{array}{l}\mathbf{2 0 2} \\
\mathbf{1}\end{array}$ \\
\hline Asia and Pacific & 4.5 & -0.2 & -100.2 & 7.4 \\
\hline Australia and New Zealand & 1.9 & -6.7 & -106.7 & 6.1 \\
\hline Caribbean & 3.3 & -2.8 & -102.8 & 4 \\
\hline Central America & 2.4 & -3 & -103 & 4.1 \\
\hline Central Asia and the Caucasus & 2.3 & -3.5 & -103.5 & 4.9 \\
\hline East Asia & 4.8 & -0.1 & -100.1 & 7.7 \\
\hline Eastern Europe & 2.4 & -5.4 & -105.4 & 4.2 \\
\hline Europe & 1.6 & -6.7 & -106.7 & 4.4 \\
\hline Middle East (Region) & -0.8 & -4 & -104 & 3.7 \\
\hline North Africa & 3.8 & -1.7 & -101.7 & 5.8 \\
\hline North America & 2 & -6 & -106 & 4.5 \\
\hline Pacific Islands & 3.8 & -2.1 & -102.1 & 3.8 \\
\hline South America & -0.1 & -5 & -105 & 3.4 \\
\hline South Asia & 4.3 & 1.5 & -98.5 & 7 \\
\hline Southeast Asia & 4.7 & -0.7 & -100.7 & 7.4 \\
\hline Sub-Saharan Africa (Region) & 2.9 & -1.8 & -101.8 & 3.8 \\
\hline Western Europe & 1.3 & -7.3 & -107.3 & 4.5 \\
\hline Western Hemisphere (Region) & 1.6 & -5.7 & -105.7 & 4.3 \\
\hline ASEAN-5 & 4.8 & -0.6 & -100.6 & 7.8 \\
\hline Advanced economies & 1.7 & -6.1 & -106.1 & 4.5 \\
\hline Emerging and Developing Asia & 5.5 & 1 & -99 & 8.5 \\
\hline Emerging and Developing Europe & 2.1 & -5.2 & -105.2 & 4.2 \\
\hline Emerging market and developing & & & & \\
economies & 3.7 & -1 & -101 & 4.6 \\
\hline Euro area & 1.2 & -7.5 & -107.5 & 4.7 \\
\hline European Union & 1.7 & -7.1 & -107.1 & 4.4 \\
\hline Latin America and the Caribbean & 0.1 & -5.2 & -105.2 & 4.5 \\
\hline Major advanced economies (G7) & 1.6 & -6.2 & -106.2 & 5.8 \\
\hline Middle East and Central Asia & 1.2 & -2.8 & -102.8 & \\
\hline Other advanced economies & 1.7 & -4.6 & -104.6 & -1 \\
\hline Sub-Saharan Africa & 3.1 & -1.6 & -101.6 & -3 \\
\hline World & 2.9 & -3 & -103 & \\
\hline
\end{tabular}

Source: IMF 2020 